\title{
МЕТОДОЛОГІЧНІ ЗАСАДИ ВИКЛАДАННЯ ЕПІДЕІОЛОГІЇ СТУДЕНТАМ СТОМАТОЛОГІЧНОГО ФАКУЛЬТЕТУ У СВІТЛІ ВИМОГ БОЛОНСЬКОГО ПРОЦЕСУ
}

\author{
І. Д. Байдалка
}

Львівський наџіональний медичний університет імені Данила Галицького

\section{METHODICAL PRINCIPLES OF EPIDEMIOLOGY TEACHING FOR STUDENTS OF DENTAL FACULTY IN ACCORDANCE WITH BOLOGNA PROCESS}

\author{
Lviv National Medical University by Danylo Halytskyi
}

\begin{abstract}
Забезпечення високого рівня підготовки лікарів-стоматологів є вимогою сьогодення, оскільки цей фах вимагає належних знань і вмінь для надання належної стоматологічної допомоги населенню. Навчальний процес передбачас оволодіння знаннями з багатьох суміжних медичних дисциплін, які у свою чергу оптимізують навчальний процес із врахуванням майбутнього фаху студентів. Організація навчально-методичної роботи на кафедрі епідеміології оріснтована на кінцеву мету навчання й професійну стоматологічну діяльність.

Providing of high level of the education of dentists is the requirement at present time, as this profession requires the proper knowledge and abilities for the grant of the proper stomatological care to the population. An educational process foresees a capture knowledge from many contiguous medical disciplines, which in turn optimize an educational process recognition for future students profession. Organization of education and methodological work on the epidemiology department is oriented to the ultimate studies aim and professional dental activity.
\end{abstract}

Вступ. У практичній діяльності лікаря-стоматолога часто трапляються ситуації, коли потрібно пояснити нові (не типові) клінічні явища, факти, процеси і прийняти креативне, творче рішення для адекватного лікування. Це завдання полегшується, якщо навчальна програма спрямована не лише на засвоєння результатів наукового пізнання, а й на розвиток творчих здібностей майбутнього лікаря, формування можливостей використання міждисциплінарних зв'язків у практичній діяльності.

Окрім того, стоматологи належать до групи високого професійного ризику інфікування на робочому місці низкою збудників інфекційних хвороб-ВІЛ, вірусами парентеральних гепатитів (гепатит В, гепатит C). За даними ВООЗ, лікарі-стоматологи займають перше місце в переліку медичних професій підвищеного ризику інфікування збудником ВІЛ-інфекції. Підвищений ризик інфікування ВІЛ лікарів-стоматологів цілком очевидний: усі маніпуляції в порожнині рота пов'язані з мікротравмами як пацієнтів, так i лікарів, що зумовлює реалізацію прямого контактного механізму передачі. Загальновідомо, що ймовірність інфікування ВІЛ лікарів-стоматологів при ушкодженні шкіри руки в 5-10 разів вища, ніж у інших медичних працівників, але нижча, ніж потенційний ризик зараження за цих умов вірусами гепатиту В чи герпесу простого [2].

Тому студенти стоматологічного факультету під час практичної роботи з пацієнтами, які на сьогодні розглядаються як потенційно хворі на гепатит В та ВІЛ-інфіковані, повинні володіти практичними навичками щодо попередження зараження цими збудниками, а також вміннями провести адекватні протиепідемічні заходи, якби виник ризик зараження цими патогенами під практичної діяльності. Власне, організація навчально-методичної роботи на кафедрі епідеміології орієнтована на оволодіння студентами знаннями та вміннями, що дозволять їм адекватно виконувати усі компоненти інфекційного контролю 3 метою недопущення поширення збудників внутрішньолікарняних інфекцій, попередження випадків професійного інфікування медичного і допоміжного персоналу та пацієнтів [1].

Основна частина. Важливою частиною освітніх програм, згідно з положеннями Болонської декларації, $\epsilon$ практична спрямованість усіх робочих програм i 
планів навчання. Вивчення епідеміології для студентів IV курсу стоматологічного факультету структуроване на 6 тематичних модулів і закінчується підсумковим модульним контролем, як передбачено типовою програмою.

Студенти отримують базові знання як теоретичне підгрунтя щодо засад епідеміології на першому практичному занятті, що дозволяє їм від другого і подальших занять перейти до інтенсивного засвоєння практичних навичок і вмінь. Колективом кафедри підготовлені і видані друкарським способом методичні рекомендації до усіх 6 тематичних модулів, та методичні рекомендації для самостійної підготовки студентів. У них подані, відповідно до нормативної бази, сучасний інформативний матеріал, алгоритми виконання практичних навичок. Практичне спрямування вивчення епідеміології досягається також за допомогою використання навчальних і життєвих клінічних ситуацій. 3 цією метою на заняттях застосовуються розроблені ситуаційні задачі до кожної теми, які розглядають вирішення практичних ситуацій із стоматологічної практики. Типові задачі також запропоновані у методичних рекомендаціях для самостійного вирішення студентами.

Основні акценти робляться на засвоєнні студентами практичних навичок при вивченні сучасних методів дезінфекції та стерилізації, що у подальшому вони будуть застосовувати у розрізі дотримання інфекційного контролю у стоматологічному кабінеті.

На кожному практичному занятті створюються умови для самостійного творчого опрацювання студентами інформаційного матеріалу, нормативної бази, та алгоритмів виконання основних практичних маніпуляцій.

Засвоєнню теоретичних знань студентами сприяє розв'язання ними проблемних задач відповідно до теми, що вивчається, а також тестових завдань. Тестова система оцінки знань також значно спрощує процес перевірки та контролю знань студентів, однак, на нашу думку, такий підхід не сприяє творчому мисленню і аналітичному підходу студентів до конкретної клінічної ситуації, не примушує їх думати, що найбільш негативно впливає на рівень знань і умінь. Ми поділяємо думку багатьох колег, що такий спрощений підхід до формування знань призводить до того, що майбутні лікарі не здатні знаходити адекватні та креативні рішення, а медицина (в тому числі стоматологія) цього вимагає на кожному кроці (при спілкуванні з пацієнтами, дітьми, батьками, колегами) $[3,4]$. Для формування креативного мислення в структурі практичного заняття введений підсумко- вий контроль, який полягає в тому, що студенти повинні подати у письмовій формі розширені відповіді на поставлені запитання.

Ще одним важливим елементом організації практично-орієнтованого навчання є унаочнення навчальних занять. Як відомо, використання наочного приладдя під час занять збільшує відсоток запам'ятовування матеріалу. Тому всі практичні заняття 3 епідеміології містять колекцію відеозаписів виконання практичних навичок, навчальних відеоматеріалів, анімованих фрагментів, таблиць і схем, які використовуються для ілюстрації інформативного матеріалу, комплектів діючих нормативних документів [5].

Поряд із стандартизованим методом навчання студентам-стоматологам надано можливість для інтерактивного навчання. На базі кафедри обладнано спеціальну навчальну кімнату з сформованим банком тестів, тематичними комплектами інформаційного та нормативного матеріалу.

Для вирішення практично-орієнтованих завдань на практичних заняттях використовується методика ігрового моделювання, за допомогою якої студент, отримавши практичне тематичне завдання, відтворює практичну маніпуляцію, згідно з алгоритмом дії.

Таким чином студенти засвоюють основні методики: дотримання правил асептики та антисептики; забезпечення адекватної особистої гігієни та догляду за шкірою рук і нігтів (алгоритм гігієнічної обробки рук й алгоритм дезінфекції рук); застосовування одноразових інструментів та алгоритм їх знезараження та утилізації; проведення I етапу стерилізації (дезінфекціi) різних груп стоматологічного інструментарію; проведення II етапу стерилізації (передстерилізаційного очищення) різних груп стоматологічного інструментарію; проведення III етапу стерилізації (власне стерилізаціі) різних груп стоматологічного інструментарію; підбору та приготування дезінфікуючих розчинів відповідно до регламентів, затверджених МО3 України; проведення контролю якості передстерилізаційного очищення та стерилізації інструментарію; використання та знезараження карпульних анестетиків; використання засобів індивідуального захисту медичного персоналу під час роботи, при передстерилізаційній обробці інструментів; проведення ультрафіолетового опромінення кабінету перед початком та після закінчення прийому хворих, умови реєстрації в журналі; проведення відповідних профілактичних та протиепідемічних заходів у випадку аварії при проведенні маніпуляцій ВІЛ-інфікованій особі чи хворому на гепатит $\mathrm{B}$, умови реєстрації в журналі тощо. 
Висновок. Таким чином, впровадження практично-орієнтованого викладання епідеміології можна досягти у разі комплексного використанню елементів моделювання практичних ситуацій, виконання студентами алгоритмів практичних маніпуляцій, застосування ситуаційних задач, унаочнення навчаль-

\section{Лiтература}

1. Значення та можливості формування професійного мислення лікаря у студентів вищих медичних закладів / О. С. Абатуров, Л. Р. Шостакович-Корецька, І. Л. Височина, О. Л. Кривуша // Проблеми безперервного професійного розвитку лікарів та провізорів : матеріали доп. наук.-метод. конфер. $з$ міжнародною участю. - Київ, 2007. - С. 399-400.

2. Банченко Г. В. ВИЧ-инфекция в полости рта. Профилактика, клиника, диагностика, лечение / Г. В. Банченко // Новое в стоматологии. - 1992. - № 2. - С. 2-7.

3. Вища медична освіта і Болонський процес : навч.-метод. та інф.-довідк. матеріали наради-семінару для наук.пед. працівників, аспірантів, магістрів (17-19 січня 2005 р.). Частина I.-К., 2005. - С. 112-115.

4. Байденко В. И. Болонский процесс: структурная реформа высшего образования Европы / В. И. Байденко. - них занять, здійснення міждисциплінарної інтеграції. Ми продовжимо пошук оптимальних схем і алгоритмів для кожного з модулів, в подальшому спробуємо оптимізувати викладання шляхом графічного представлення алгоритмів стандартних дій та процедур.

[3-е изд.]. - М. : Исследовательский центр проблем качества подготовки специалистов, Российский новый университет, 2003.-С. 28-30.

5. Модернізація вищої освіти України і Болонський процес : матеріали до першої лекції / М. Ф. Степко, Я. Я. Болюбаш, К. М. Левківський, Ю. В. Сухарніков; відп. ред. М. Ф. Степко. -К., 2004. - 24 c.

6. Gallant Medical management of HIV infection / G. Jonn Barlett, E. Joel. - Jobns Hopkins University School of Medicine. -2003. - P. 1.46.

7. The European Higher Education Area - Achieving the Goals. Communique of the Conference of European Ministers Responsible for Higher Education, Bergen, 19-20 May 2005. Режим доступу: http//www.bologna-bergen 2005.no/. 